\title{
from free labor to family allowances: labor and African society in colonial discourse
}

FREDERICK COOPER-University of Michigan

In 1889, at the height of their competition for African territory, the imperial powers met at Brussels to discuss their obligations in the colonization process. The key resolutions called on all colonizers to abolish traffic in slaves, weapons, and liquor. The fact and the contents of the agreement are revealing; rival powers were defining themselves through a formal treaty as a community of civilized nations holding each other to certain standards. At the same time, they defined Africans as people who enslaved each other, who were violent, and who could not contain themselves in social interaction.

This is an article about changing moral standards in colonialism, as shaped by the interaction of different imperial powers and above all by interaction with colonized peoples. It concerns free labor ideology: the belief that a labor market unconstrained by bonds of personal servitude and governmental coercion provides the best means to achieve a just wage, just working conditions, and social progress. This concept was central to the European indictment of African society in the years of conquest: the antislavery publicists shaped an image of Africa based on the antitheses of slave and free labor, of tyrrany and civilized government, of closed, defensive, subsistence-oriented communities and open market economies, of stagnation and progress. But such oppositions became much more difficult to sustain in practice: making labor power, not the person of the laborer, into a marketable commodity meant more than abolishing a legal category or status, but creating new cultural and social forms, tasks that involved a level of

From the early 19 th century, the European debate over the slave trade and slavery pioneered a new international discourse in which the concept of free labor defined a universalistic standard for the conduct of Europeans in colonies and non-European societies. Implementing free labor, however, entailed a confrontation with the particular work culture and values of local communities, from ex-slaves to independent peasants. This article examines the connection between imperial powers' critiques of each others' conduct-and the role of international fora in defining imperial morality-and their encounter with African social structures. Colonial states were inextricably drawn into confronting Africans as social beings: first in trying to induce them to become disciplined wage workers, then to contain the conflicts unleashed in places of work and urban residence. By the 1940s, this meant exporting to Africa European approaches to containing class conflict. Colonial cities became less the realm of the colonial expert and more that of the "industrial relations" specialist, who argued against migratory labor and in favor of taking Africans out of their cultural milieu and reproducing their families under the eyes of European welfare experts, even if this implied paying family wages or family allowances that exceeded the free market price of labor. Only with decolonization did France and Britain take themselves out of the social and political intimacy of the workers' milieu and participate in a new-or rather old -international discourse on the moral and social virtue of the free market. [labor, migration, reproduction, slavery, welfare, decolonization] 
intimate involvement in African communities that British and French bureaucracies could not attain. The more ambitious schemes for converting slave to wage labor failed, giving rise to a more formalistic opposition of colonial powers to African slavery and government forced labor and a new attempt to make the nontransformation of African culture and society seem desirable.

But the problem was not just that getting Africans into wage labor was a many-faceted social process, but that once inside places of work, Africans were still social beings, and the relationships and attitudes they formed among themselves helped to determine how efficiently they worked and how much danger they posed. This article focuses on the plunge colonial powers took from the universal dichotomy of free and coerced labor into the murky waters of social life, and the way in which they got themselves dry again. A sharp break occurred in both British and French thinking about the relationship of wage labor to African society in the 1940s. Even tiny working classes could strike, and they were threatening the narrow channels of colonial commerce, just as the war and the weaknesses in imperial economies that it revealed underscored British and French need for their empires. At the same time, the idea of "self-determination" was becoming salient in international politics. Trying to articulate a forward-looking colonial social policy-while trying to contain workers' reactions to the strains of their daily lives-colonial officials began to think that shaping an African working class might be desirable. Such a class could be separated from the dangerous masses who moved back and forth between vulnerable cities and the backward countryside.

Such thinking was both universalist and ethnocentric: the European precedent of taming a once truculent working class became the model for bringing orderly progress to Africa. This led the imperial powers to set forth a universal social standard-based on the perceived experience of European workers--for how African workers should live, overriding the economic standard of the market wage. Thinking about the African worker as an acultural industrial man represented a sharp break in European conceptions of African society, yet outside the sphere of capitalist production and reproduction, African culture was portrayed as more traditional and backward than ever.

We then come full circle. Decolonization brought back the purism of free labor ideology. International agencies and academics told African governments to pay workers no more than the market wage and to reduce social services, and they left fledgling governments to face the social and political consequences if workers could not maintain a minimum standard of living or reproduce themselves. This article is schematic and selective in coverage and bibliography; its aim is to suggest connections over long periods, across wide distances, and between discourses and practices; it necessarily glosses over differences, peculiarities, and nuances, all of which deserve further attention within the framework developed here.

\section{emancipation and imperialism in theory and practice: a cycle repeated}

The discussion begins after a very important act had already been played. The British government, in particular, had already faced the ambiguities of implementing free labor ideology after the emancipation act of 1833 , even as it succeeded in obtaining a European consensus on the immorality of the slave trade.' Officials had expressed both hope and skepticism that universalistic economic considerations-the individual's pursuit of gain-would induce black ex-slaves in the West Indies to work for wages (Davís 1974, 1984). In fact, they soon learned that ex-slaves had their own conceptions of economy.

In Jamaica, most notably, freed slaves sought to combine subsistence cultivation, marketing of the produce of their hillside gardens, and periodic forays into earning wages on sugar plantations. As the planters tried to tighten discipline on the plantations, ex-slaves distanced themselves. Sugar exports declined as other productive activities increased (Holt, forthcoming). The 
colonial office saw the slaves' tendency to remove themselves from the plantation zone as a reversion to "savage sloth," and argued that land had to be tightly controlled to insure that exslaves sought wage labor: "The dread of starving is thus substituted for the dread of being flogged. ... The 'Emancipist' undergoes a transition from the brutal to the rational predicament." The colonial secretary, three years after emancipation, took this argument one step further: kept from straying in search of land, ex-slaves would be "more open to civilizing influences, more directly under the control of Government, more full of the activity which is inspired by common wants, and the strength which is derived from the division of labour; and altogether ... in a sound state, morally, politically and economically, than if left to pursue its natural course."

This last phrase is revealing: already the "natural course" was proving inadequate; free labor was not driving all else before it. Ex-slaves on British islands, with their own ideas about remaking their lives, were not making British planters' sugar production competitive with that of Cuba's slaves. A silence opened up in colonial discussions of the West Indies: as Trouillot (this volume) notes, the growing semiautonomous peasantry could not be acknowledged as such in a dialectic of property and labor, of work and idleness. But in Jamaica, the clash over land led to violence in 1865 , and fears of disorderly blacks took their place alongside concern with idleness. Idleness and disorder came increasingly to be explained in racial terms. The mere freeing of labor appeared more and more inadequate and any ambitions to spread progress to backward peoples seemed to require direct control.

This experience conditioned attitudes toward Africa. So, too, did the fact that the abolition of the slave trade-along with the increase in agricultural exports from Africa to Europe during the course of the 19th century-led some African societies to import more slaves and use them more productively. Whatever the nature of these slave regimes, their growth spread violence in the vast catchment regions on which the reproduction of the slave population depended. Commerce, it seemed, was not leading to the generalization of human progress, but to its confinement to certain regions and certain classes.

That was the point taken up by David Livingstone, Cardinal Lavigerie, and the other antislavery publicists of the $1860 \mathrm{~s}$ and thereafter; they portrayed Africa as a slave-ridden continent, and their critiques extended beyond enslavement as such to the violence and tyranny of African rulers and the unchanging backwardness of cultivators. Livingstone portrayed the slave trade as "an insurmountable barrier to all moral and commercial progress," destroying the order necessary for normal trade, ruining incentives to engage in agriculture or wage labor, inducing people to accept demeaning forms of protection, and keeping people in a state of defensive isolation rather than one of progressive interconnection and receptivity to new ideas. ${ }^{3}$ Even outside of slave trading zones, explorers and traders attacked the violence and unpredictability of African rulers and the reluctance of Africans-particularly male Africans-- to work (Cairns 1965:80-81, 194-198). The African king stood beside the slave trader, accused of imposing the brutal predicament and opposing the rise of the rational one. ${ }^{4}$

This new trend in antislavery writing provided a vivid way of bringing Africa into a wider discourse on society and progress: a clean break was needed to create in Africa social structures capable of orderly reproduction and economic expansion. The influence of such thinking helps to explain the concern of Britain, France, Germany, and Belgium-expressed at their meeting in Brussels in 1889-to spell out the standards for conquering powers and their stress on free labor, order, and self-discipline. Their agreement pointed to the desire of imperial powers to delineate a new colonialism, explicitly and collectively rejecting the freebooting, the looting, the enslaving of past colonialisms in favor of building institutions for the systematic and controlled exploitation of colonial resources. Lord Salisbury called the Brussels Conference the first in history that met "for the purpose of promoting a matter of pure humanity and goodwill" (Miers 1975:xi). 
Free labor ideology was thus embedded within the system of imperial self-justification from the start, and the Brussels treaty made it likely that different states would keep an eye on each other. Within Great Britain, not only the old Anti-Slavery Society (later joined to the Aborigines Protection Society) and the missionaries, but a group of West African merchants (notably John Holt and E. D. Morel) who had a vested interest in a market model of imperialism insured that government actions would be subject to critiques within the establishment. ${ }^{5}$

The process of conquest itself necessarily involved tests of power with slave trading African polities, and invaders began to evoke their heroic struggles against slave traders and the peaceful, fecund world they were creating for the Africans. ${ }^{\circ}$ Conquest reinforced antislavery ideology in another way: by attacking the power of slavers, providing alternative sources of protection to dependence on slaveowners, and introducing new chances to obtain subsistence or income, conquest made it easier for slaves to flee or disobey (Cooper 1980; Miers and Roberts 1988). Slave resistance made it difficult for colonial regimes to take African systems of production as they were: slavery became less productive and more disorderly, and colonial regimes were in the politically untenable position of having to take specific actions, such as returning runaways, to support slavery.

Thus, even colonial officials who realized the difficulties of following up on antislavery ideology most often found they had at least to acquiesce to the ending of slave labor. But the British tried some more radical experiments in the enforced transformation of slave to wage labor. Frederick Lugard argued that even if slavery were "well suited to the African," it was incompatible with progress:

In the first place, slavery cannot be maintained without a supply of slaves, acquired under all the horrors of slave-raids, and transported with great loss of life from their original habitation; this results, not only in much human suffering, but also in a decrease of the population, and consequently in a decrease of the productive capacity of the country; secondly, no people can ever progress if personal initiative and personal responsibility is denied to them. ... That existing slaves may be happy in their lot is no argument to the mind of any one who aims at the progress of the race in a remoter future [1906:135].

Lugard, in northern Nigeria, wanted to turn slaveowners into landowning, wage-paying agricultural capitalists, and slaves not into peasants but into workers.

So, too, did officials who had taken over Africa's most effectively organized system of slave plantations, on the East Coast of Africa. Even missionaries agreed-using the language of class of contemporary London - that slaves, if not supervised, "would tend to produce a demoralized and dangerous class of people, such as would be sure in the future to embarrass the good government and to mar the prosperity of the country." bate: was ending the legal status of slavery itself sufficient to create a wage labor economy, or should the state intervene to ease the transition and maintain discipline? The latter course prevailed, and abolition in Zanzibar in 1897 was accompanied by ratification of slaveowners' land titles, compensation intended to help them pay wages, and pressure to get ex-slaves to accept year-long labor contracts on their former owners' plantations. A campaign against vagrancy, theft of agricultural produce, drinking, and personal violence was put forth as a means of instilling discipline into unruly ex-slaves and creating a society divided into those who owned property and those who worked. The purists of the labor market-led by Quaker missionaries-opposed the government's support of contracts: discipline during the contract period relied on the brutal rather than the rational imperative.

In practice, the main problem was that ex-slaveowners did not necessarily play the proper role of capitalist landlord or ex-slaves that of worker. Northern Nigerian elites preferred extorting tribute from small farmers to supervising the production process itself until an anxious government gave up its crusade for agrarian capitalism. Ex-slaves in East Africa established themselves as squatters and tried to combine casual labor, subsistence cultivation, and cash crop production to avoid becoming dependent on any one of them (Lennihan 1982; Cooper 1980). In French West Africa, a governor-general could boast in 1905 of creating out of exslaves "a new class of free and salaried workers," but in fact many ex-slaves had gone to their 
ancestral lands or taken up cultivation on their own, or else entered into complex, long-term social and religious relationships with old or new elites, hardly constituting a class for whose labor anyone could bid (Klein 1986; Miers and Roberts 1988).

As in the West Indies 70 years previously, colonial officials in parts of Africa were trying to maintain a class system and export production, using state power to preserve property rights and to inculcate work discipline, while abolitionist critics protested infringements of the purism of the labor market. Colonial states were at times willing to promote proletarian discipline for the benefit of nonwhite ruling classes; their ability to redefine class relations in a European image was nevertheless very much in question.

The logic of the argument for turning slaves into wage laborers applied equally well to peasants: instead of facing slaves' brutal predicament, peasants-growing their own food-faced no predicament at all. Some missionaries tried to imagine an African world of sturdy cultivators accepting Christian self-discipline, hard work, monogamy, and the outward, commodified signs of inner salvation-from Western clothing to square houses to plows. But it was far from clear that converts could not incorporate Christian values and Western commodities into their own, quite different social visions (Beidelman 1982; Comaroff, this volume). Where the demands capitalist development made on Africans expanded the most rapidly - in South Africathe gradual extension of market relations and individualistic values proved completely inadequate: labor discipline was achieved through a systematic assault on the access of African cultivators to the land.

A now large literature details the pitfalls on the road to capitalist development in Africa (reviewed in Cooper 1981). Like the linkage of economic and social progress with slave emancipation in the 1830s, the linkage between progress and imperialism at the end of the 19th century foundered in the encounter with people with their own conceptions of economic life. Colonial states and humanitarian lobbies were brought directly into the messiness of social structure. At the turn of the century, governments tried to create African proletarians, successfully in South Africa, not so in northern Nigeria or East Africa; they tried to ignore social questions where produce flowed smoothly and order was maintained - as in the Gold Coast-and they learned to accept what previously had seemed undesirable, such as the Muslim marabouts of Senegal who mobilized labor in their own ways for peanut cultivation. States used their fiscal and regulatory powers to shape the parameters of commerce, but had to accept the limits of their ability to restructure production. After a couple of decades of experience colonial ideologies would lose the radical, interventionist implications of the late 19th-century critique of African society and find a new mission in preserving elements of African culture.

\section{the critique of forced labor and its limitations}

These same years were crucial to determining how serious European nations were about each other's practices. The key test came in King Leopold's Congo. In 1908, over two decades after European powers had agreed to let Leopold rule personally over the Congo and after years of controversy over the horrors of forced rubber collection in his domain, they pressured him to convert the Congo into a proper Belgian colony. Although rubber collection actually ended because the rubber was exhausted, the cession of the Congo showed what kind of colonialism was unacceptable in polite company.

There is more to the scandal than an international campaign of the morally righteous against unscrupulous greed. The man who helped break open the scandal, Roger Casement, was heir to the spirit of antislavery ideology; his allies in the exposé of Leopold included leading British West African merchants who practiced what they preached. Their attack not only developed the imagery of horror-the raids on villages, the murder and torture of people who failed to meet their rubber quotas-similar to antislavery literature, but it did so in stark contrast to the 
benign appearance of market transactions. Yet such a contrast presumed what Leopold's henchmen could not: that Africans had already accepted the rational world of markets (Taussig 1987).

In extracting labor by terror, the companies not only created Leopold's economy, but Conrad's Africa. The very act of terrorism created an aura around its victims: African irrationality that impeded rational men from doing business, the savagery of Africans that justified brutality. Taussig (1987) argues that terror had its aesthetic qualities, linked to the exoticism of the primitives with whom the terrorist became intimately engaged, and to the conceit that the savage was in his own way powerful and dangerous, with magic powers that the white man simultaneously scorned, feared, and wanted.

Casement wanted to naturalize the free market just as the terrorists wanted to naturalize their version of African culture. His powerful writing indeed helped undo the horror, but to undo a precisely bounded horror. The deeper questions of the conflict of cultures, of the images of savagery, and of the peculiar nature of capitalist economic rationality and the difficulties of transporting it to Africa lay unexamined. At the very end of the colonial era, savagery and countersavagery would reappear in European discourse on Africa, in a final assault on primitiveness in the name of modernity.

The reformist critique of imperialism gone wrong - extended later to Portuguese and Liberian labor roundups for plantations on offshore islands (Duffy 1967; Sundiata 1980)_emphasized by contrast the morality and normalcy of colonial rule. All the while, South Africa was reducing African land rights, uprooting squatters, and enforcing discipline on African workers through pass laws, control of residence, and other means. South African labor policy has long had its principled critics, but on the international scene they had no sure handle to pry open the legalistic and systematic approach to creating a proletariat. Africans might be suffering the costs of progress, but not the reactionary oppression of slavery.

France and Britain, facing in most of Africa a situation where Africans could distance themselves from the "rational predicament" of wage labor, themselves often skirted the boundaries of free labor ideology, and faced regular criticism from the purists of the labor market. The critics frequently used the word "slavery" to dramatize policies that strayed beyond the bounds (for example, Harris 1919). All regimes evoked public purpose, above all the need to develop transportation networks to open Africa, to justify the provisional use of forced labor. French officials employed a military metaphor: they recruited young men to the army, then hived off the "deuxième portion du contingent" for involuntary, low-paid, public works labor. In fact, official recruitment of unwilling laborers for private concerns continued in French Africa until 1946 (Fall 1984; Echenberg and Filipovich 1987).

The British government insisted that it abhorred forced labor, but practiced it in mines in the Gold Coast and Rhodesia. Words like "recruitment" were carefully employed, but Africans in Rhodesia used the word chibaro-meaning slave in local languages-for recruited laborers. During World War II, the British "conscripted" labor for coffee farms as well as tin mines, and afterwards they cited soil erosion to justify forcing people to labor on conservation projects (van Onselen 1976; Killingray 1986; Throup 1987).

But in African villages, relations between chiefs and people were nested in a complex of affinity and power far more subtle than the distinction between coerced and free labor. As a British official in Kenya put it, obtaining labor from a chief for the benefit of white settlers "depended on how far he could be induced to exceed his instructions." A rare honest inspection report into the French system commented in 1931, "No written instruction was ever addressed to administrators on their conduct in this matter. And yet everyone knew the boss's wishes, everyone trembled for his promotion and did not dare formulate explicitly any criticism whatsoever." ${ }^{\prime \prime}$

A new silence opened up in colonial discourse: the realities of labor recruitment could not be discussed forthrightly. Even when a sympathetic minister in Paris ordered recruitment for 
private individuals to stop in 1936, he could never be sure that the persuasion - the "apostolat du travail" - to which his local officials said they were limiting themselves was in practice very different from obligatory labor. In British Africa, the often eloquent critique of official coercion for private profit did not penetrate the patterns of landownership and power that actually shaped the conditions of labor. ${ }^{9}$

Already by the 1920 s the free labor question in various colonies was becoming less salient (Berman and Lonsdale 1980). The new equilibrium was as much a consequence of decreasing European aspirations as of the growing necessities that pushed Africans into labor and produce markets. The areas from which most export crops came were in fact quite limited, and the social relations of production in them were varied. The islands of European production-the Central African mines, the Kenya highland settler farms, or the lvory Coast plantations-drew their labor supply from large catchment areas. It came forth-and not simply because Europeans wanted it this way - for relatively short periods of time. A small demand for manpower required large numbers of potential laborers, and worked most predictably when large regions were so impoverished that wage labor became part of the life cycle. By the late 1930s and 1940s, the adverse demographic and economic effects of this pattern were beginning to enter official and unofficial discussions (Eboué 1945; Davis 1933; Wilson 1941).

In the Depression years, African agricultural and labor systems-at a large cost to Africansproved quite good at contracting: problems of social security were sloughed off onto the countryside, but cash-poor Africans still had to supply at least some crops or labor. Still, officials began to realize that such a system would respond poorly to renewed demands for production: higher crop prices would make African cultivators more independent. A report from French West Africa一at a time when two percent of the population was working for wages-warned that recruitment had already reached its limits. ${ }^{10}$

That is to anticipate the rethinking of the labor question that began in the late 1930s. But before that, another sort of imperial myth had its reign. Europeans' self-portrayal as bringing a slave-ridden, barbarous continent under civilized and progressive rule gave way, by the 1920s, to the contention that rural Africa was tradition-bound, stable, living in the organic harmony of ancient social structures (Ranger 1983:247-251). Lugard, who had once vainly tried to make northern Nigerian slaveowners into agricultural capitalists, made the myth a policy: indirect rule (Lugard 1922). French officials eventually applied their own pastoral imagery to Africa and supported development through peasant production within traditional communities. Urban workers were termed "detribalized," or a "floating population"; they were more of an aberration or a pathology than a normal part of colonial society." Colonial officials now needed to reconcile themselves to the limits of their own power to exploit African resources and labor systematically. Some of them publicly lamented the mediocrity of imperial economic accomplishments, but in both Britain and France calls for a new round of interventionist development in the 1920s and 1930s came to little (Constantine 1984:30-61; Rich 1986:27-49; Marseille 1984).

In this context, free labor ideology became formalistic, although it remained explicitly international. The League of Nations issued its "Slavery Convention" in 1926, reminding colonial powers to stop the slave trade and slavery, while asking the International Labor Organization to investigate "the best means of preventing forced or compulsory labour from developing into conditions analogous to slavery." This was done in the ILO Convention of 1930, which strongly condemned forced labor for private purposes and created elaborate regulations for compulsory public works labor, arguing that it should be phased out (International Labor Organization 1929:1-2; 1939:179-193). In practice, free labor ideology could be reaffirmed at the expense of minor states, Liberia for instance. The French-believing their colonies had less potential manpower than those of the British-were in the awkward position of being unable to ratify the ILO convention of 1930 until the Popular Front finally did so in 1937. This decision, in turn, reflected senior officials' concern about the hypocrisy of their own discourse: 
We lie in France, in Europe, in the entire world, in Geneva and at the International Labour Organization when, regulations and circulars in hand, we speak of the organization of public works labor in the colonies. We dishonor our colonial administration and we demoralize our civil servants by asking them to apply, on paper only, regulations inapplicable in practice. ${ }^{12}$

We see here both the influence and the limits of international codification of free labor ideology. It treated forced labor as a clearly identifiable and immoral administrative practice, unambiguously separated from free labor, but it did not address the complex context in which Africans worked: the visions of economic life through which they tried to allocate their time and effort and the web of rural power through which administrations and chiefs extracted labor power. But by the mid-1930s, workers themselves were forcing colonial officials to examine the implication of wage labor, and after the war Britain and France would once again be trying to rethink their labor policies as part of a coherent vision of imperial progress. ${ }^{33}$

\section{toward an industrlal soclology for Africa}

Before World War II, international discussions of labor in Africa focused on the issue of force; Africa was remote from the active rethinking of labor control, welfare, and industrial relations going on in Europe. ${ }^{14}$ When international gatherings resumed after the war, a different set of issues was on the table. The 1944 meeting of the ILO called attention to the responsibility of independent states for "the well-being and development of dependent peoples," and discussed the question of setting "international minimum standards and ... the improvement of these standards." Mention was made of "public health, housing, nutrition, education, the welfare of children, the status of women, conditions of employment, the remuneration of wage earners and independent producers, migratory labour, social security, standards of public services and general production." At its next meeting in 1947, a new ILO convention on social policy looked toward the application of ILO standards for European workers to the colonies (ILO 1944, 1947).

What happened to change the agenda? At the end of the war, Britain and France were both desperate to mobilize inadequately exploited African resources to revitalize troubled economies. At the same time, the words "self-determination" had come into international vocabularies, and colonial powers now justified their continued rule as necessary to guiding backward areas toward social and economic development; they were suddenly eager to make African living standards a matter for public discussion (Marseille 1984; Louis 1978; Cooper 1987). Both elements of development strategies implied the need for more labor, more efficient labor, and better conditions for labor.

But the new language appeared in a context which suggests another cause: in official reports on the waves of strikes between 1935 and the late 1940s. These strikes were not routine industrial relations disputes, but mass urban events, following the fluid lines of a labor system in which most Africans moved into and out of particular jobs and into and out of the category of "worker." The copper mine strike in Northern Rhodesia in 1935 spread from mine to mine to other inhabitants of the mine towns; officials thought it was spreading (in the absence of a union) via religious organizations, dance societies, personal networks, and mass gatherings. The investigating commission, labeling the problem a "disturbance," thought it could be contained by more systematic repatriation of workers who had completed contracts and by reinforcing traditional authority (Northern Rhodesia 1935; Parpart 1983).

The West Indian strikes and riots of 1935-38 took officials aback and made it difficult for them to think of African tradition as the remedy for colonial problems. And in 1940 a second strike in the Copperbelt, resulting in more deaths, revealed that the problem in Africa remained to be solved. In Parliament, a future colonial secretary had observed shortly earlier that thinking of such events as "disorders" made them harder to solve than if they were considered "simple industrial disputes." The search had begun for a vocabulary that would put African workers into a sociology of industrial capitalism rather than an anthropology of colonial society. ${ }^{15}$ 
A series of strikes in East Africa's leading port, Mombasa, helped focus such thinking. The commission studying the general strike of 1939 saw that casual dock laborers, working by the day, were part of an amorphous urban mass, much larger than the number of people working at any one time, straining housing and other resources, and creating a wide field for disorder. It hoped that a compact labor force, steadily employed, could be given better and more controlled housing and isolated from its fellow urbanites. During the war, attempts were made to settle disputes by "scientific" adjustments of wages, based on fluctuations in the cost of food, clothing, and other seemingly objective components of a minimum standard of living. In 1945 , yet another commission reentered the realm of the social. A new strike movement had revealed the presence of an "urbanized working class," many of whose members had spent years on the job and lived with their families, but who had no more lifetime opportunities than casual workers. All sellers of labor power shared a common "class consciousness, complicated by race consciousness." Continued turbulence could be averted by separating out a class of workers from the urban mass and allowing them to become "civilized" by bringing up their children in the city in decent conditions. The committee turned around the central rationale of prewar migratory labor policy: "the evils which are commonly attributed to 'detribalisation' can only be cured by more complete detribalisation" (Kenya 1945; Cooper 1987).

Strike movements and urban riots in Nigeria $(1942,1945,1949)$, the Gold Coast (1947, 1948), Tanganyika (1947), and Zanzibar (1948) confirmed such lessons. The argument about order applied to productivity as well: if workers and their families remained at the workplace, Africans would become acculturated to urban and industrial environments, and productivity would rise. The key was to separate workers from the backward countryside (see for example Northcott 1949, and for a fuller analysis, Cooper 1987).

When French officials arrived at a similar perspective, it represented a rapid reversal. After the collapse of Vichy, officials revived the Popular Front's "politique du paysannat," arguing that Africans should advance within their own village society, avoiding the formation of a proletariat. ${ }^{16}$ Even more revealing, forced labor was still an issue. French officials in 1944 rehearsed all the old arguments about the virtues of free labor-although they had been especially worried about the demographic consequences of pulling Africans from their villagesbut had so little faith in the free labor market that they proposed phasing out official recruitment

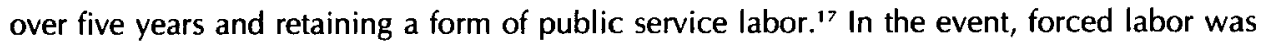
eliminated after two years, victim of the need to create stable political institutions and the utter incompatibility of allowing electoral politics and labor roundups to coexist. It was Félix Houphouët-Boigny of the Ivory Coast, the kind of African "évolué" with whom the French wanted to cooperate, whose political mobilization of the lvory Coast countryside made recruitment impossible and who, in the Assembly, proposed the law that abolished it. ${ }^{18}$

One reason local officials were content with this turn of events was that Houphouët and his fellow Ivorien planters were in the midst of organizing another form of work: they attracted northern migrants to their forest cocoa farms, promising a share of the harvest as well as wages and establishing a relationship with workers that was more long-term, more like tenancy, more nuanced than classic wage labor. Not only was the problem of forced labor formally resolved by the 1946 law, but the more general question of agrarian labor in the lvory Coast disappeared into an African world that colonial officials did not have to probe. ${ }^{19}$

By this time, French officials had been thrust into a modern resolution to another labor crisis. In early 1946, a two-month long strike movement, including a general strike lasting 11 days, shut down Dakar, the leading city of French West Africa. At one time or another, the movement involved civil servants and ordinary laborers, clerks and market sellers. Officials feared it would spread to peasants.

The Governor-General reported that he could not stop the strike or maintain the policy of restraining wages and prices. His confession of powerlessness revealed that colonial officials could not act as colonials in this delicate situation. Instead, they invoked metropolitan concepts 
of settling industrial disputes. A labor inspector arrived who believed "There is a technique to organizing work, as with everything, and it cannot be improvised." He set out to negotiate with individual unions, seeking accords with specific branches of the work force and the establishment of hierarchical pay scales within each branch. Officials conceded substantial wage increases for most workers, as well as family allowances and other emoluments to all regular government workers-implicitly admitting that Africans had the same needs for social security as did Europeans. ${ }^{20}$

In ensuing years, the French labor inspectors kept arguing that "a complete hierarchy" of wages and benefits would both avoid "a climate of social trouble and a strike that would rapidly become general" and "separate out an African elite." Seeking a work force better adapted to the "rational modernization of the economic structure of the country," it was necessary "to select this manpower and to improve, inspired by methods tried out elsewhere, its professional training. Thus it can be simultaneously better paid and worth more." Wages, in any case, had to be sufficient to encourage workers to acquire skill and above all "to make the family situation less unstable. ${ }^{\prime 21}$

The contents of this argument were not new; applying it to Africa was. An African worker was a worker, and the place of a worker in a rational economic structure fitted a pattern that had been worked out in Europe. Even the six-tier wage hierarchy that became the norm in Senegal after 1946 came straight from French precedents, and the ensuing debate over colonial labor legislation began with the text of the metropolitan Code du Travail. For their part, West African trade union leaders were remarkably quick to take up the idea of a universal industrial man-with common behavior patterns and, surely, common needs. "Your goal is to elevate us to your level; without the means, we will never succeed," said one union leader at a bargaining session, leaving his opposition speechless. The slogan "à travail égal, salaire égal" became a rallying cry; French officials could not formally deny the validity of the claim, and even insisted in private that they accepted it. ${ }^{22}$ Officials in fact wanted to believe that the metropolitan model of industrial relations would contain African labor disputes, that Africans would quickly learn the skills and habits of industrial men, and that their families would acquire the consumer habits-and hence the predictability-of European workers.

Unable to defend inequality among workers, officials tried to define who was a worker and exactly what rights he or she had: the debate over the Code du Travail for Overseas France lasted six years. The comprehensive nature of the proposed legislation politicized the labor movement, and its success, above all in the West Africa-wide general strike of November 1952 that jarred Paris into final action, gave it a new self-confidence.

The final language excluded "customary" laborers from its coverage. The act included people compensated solely by wages and eliminated thousands of people compensated by access to land or shares in crops. For those classified as workers, provisions were modeled on the French Code: a 40-hour week, paid vacations, accident insurance, trade union rights. So much had the discourse changed, that the patronat-the old defenders of colonial privilege--could find no better argument against the code than equality, professing alarm that the Code discriminated against peasants in favor of workers (Moreux 1953). The right had taken the language of equality from the left; they would bequeath it to the purists of the market in the post-colonial era.

This brings us back to the international scene. France and Britain had been trying to maintain a common ideological front in defense of enlightened imperialism (Michel 1983). A new organization, the Inter-African Labour Conference, began regular meetings in 1948, with the participation of France, Britain, Belgium, South Africa, Portugal, and the Federation of Rhodesia and Nyasaland; its resolutions show the translation of the results of concrete struggles into accepted principle. The first meeting came out in favor of trade union rights; minimum wage legislation; vocational training; developing programs of "social security" to insure against all risks "and to assist the wage earner in meeting his immediate family obligations"; old age pen- 
sions "where tribal organisation has ceased to be effective"; and efforts toward "increasing the wage-earning capacity and general standard of living of the people of Africa and the creation of a well-balanced state of society." In 1950 came more specific standards, and above all a section on "stabilisation and migration of workers." It began with a list of the "social evils" stemming from migration, and its proposals to regulate whatever migration still took place were specific enough to evoke a Portuguese dissent. But the goal was for workers, except for temporary labor, to be "established permanently in residence with their families at or near their places of employment." Efficiency implied stabilization and that meant good housing and diet, "encouragment of normal family life," and some form of "social security." 23

We are far from the free labor market, much closer to a notion of workers having universal needs that can be objectively understood, measured, and met. The most revealing issue of all was family allocations. In 1953, delegates agreed that wages, social services, and benefits paid to workers "should take account of and include provision for his family responsibilities." Discussion focused on cash or in-kind allowances paid by the employer or the public and given on a per child basis for prenatal and maternity services and for the cost of raising children. The benefits should go "to workers who, by reason of their being detribalised, no longer benefit from the traditional help enjoyed by workers who have remained in their tribal environment."24

France, along with Belgium, was responsible for the 1953 text, which was based on domestic policy. Striking African civil servants had forced the issue onto the agenda in 1946, and lower ranking civil servants had won a portion of the allocations given to the top ranks. This inequality proved impossible to defend publicly, and a 1950 law established the principle of equal pay and allocations for equal work within the civil service. ${ }^{25}$ The Code du Travail accepted the idea of family allowances for workers-as it defined them-in the private sector, but left open the question of implementation.

This immediately put family allocations onto the top of every list of demands from the labor movement, which planned demonstration and strikes, and led the Governor-General to fear "generalized agitation" and "social malaise" that would "undermine our authority" unless speedy satisfaction were given. ${ }^{26}$ The experts worked out a relatively modest and affordable plan, vehemently opposed by the patronat. It did not apply to the population in general-as did family allocations in France-but only to wage earners as defined by the Code du Travail. In making the case for family allocations, French officials expressed the fear that working men "who were the most able-bodied, and as a result the most useful element from a demographic point of view" faced such difficult conditions of family life that they tended toward "abstention in the domain of marriage and of procreation"-a concern with the quality of reproduction that bears comparison with issues raised by Stoler (this volume). At the same time, they expressed the hope that providing aid to workers' families would not only promote stability in employment, but would lead to social and cultural progress: "the disaggregation of the traditional family corresponds to an emancipation, a liberation of its members, of which we should not complain." Social progress had its price:

the African wage-earner, head of a family, above all the detribalized urban worker, runs into particular difficulties from the fact of having to support a family, notably when, having attained a certain level of social evolution and of stabilization as a worker, he tends to base his conditions of life on those of the European worker. ${ }^{27}$

It was so obvious to officials that the wage worker they were discussing was male that they did not need to say so. The assumption reflects a mixture of French expectations of sex roles and African behavior (however caused) in the labor market: wage labor, as opposed to other forms of work, was in fact a largely male domain. But the perceived relationship of gender and work had changed during the colonial era. The precolonial male was often portrayed as averse to steady and productive labor-he was sapped by slavery and the violence of savage life, and he left agricultural production to women. But in the 1950s vision of economic development, African men had become at least potentially productive, and women remained primitive cul- 
tivators and the bearers of backward culture. The plan for family allocations assumed a working father and a child-raising mother, who would be required to submit to medical consultations during and after pregnancy and who would have to send the children to school in order for her family to receive the benefits that derived from the father's employment. Workers would be induced to bring their women and children out of village life and place biological and social reproduction under the aegis of doctors, nurses, schoolteachers, and bureaucrats. ${ }^{28}$ Surveillance would be as much a part of the new Overseas France as of the old, but now it would be the responsibility of the professionally qualified guardians of health and education, not of colonial generalists who knew their natives.

As plans were drafted and redrafted between 1950 and 1956, officials became increasingly aware that their own arguments had been seized by the labor movement, for whom family allocations had become a leading issue, and the focus of a renewed attempt at organizing West Africa-wide strikes. The labor inspectors' dream of a self-reproducing labor force became their nightmare: social engineering was not to be the work of social engineers, but part of a political process that built its own momentum, feeding on African victories as well as French sociological theory..$^{29}$

British colonial officials avoided part of the problem, but only part. They feared exactly what happened in the French case: that state-mandated family allowances would make workers think "that their interests could be better advanced by political agitation than by action in the industrial field." Yet these same officials were convinced that wages still had to support a family. The conservative colonial secretary in 1954 explicitly put the necessity for a family wage above the principal of the free labor market: "even where the 'bachelor wage' still represents the supply price of labor, it may be below the level of wage necessary to secure efficient production." 30

British officials thus ended up with a sociology of work similar to that of their French counterparts. Although they escaped wide challenges from unions, they had more trouble with specific ones, being unable to invoke a general labor code whenever employers resisted paying the costs of a stable work force. In key areas like the Copperbelt and Mombasa, weak industrial relations machinery could not contain disputes, and officials turned to African politicians and trade unionists, who acquired prestige among Africans and cautious respect from officials for settling conflicts that whites could not solve (Cooper 1987; Parpart 1983).

Both French and British colonial governments calculated the costs of social reproduction independently from the market wage, and sought a stark separation of industrial culture from African culture. Their sociological dualism echoed the dualism in vogue in economic theories of the time (Lewis 1954). A French study in 1953 argued that remaking African attitudes to time and work discipline was difficult but essential.

It is exceptional that a black accepted the need to carry out his effort beyond the simple task in order to increase his gains. For that to happen, it is necessary that he has been profoundly Europeanized, that he has adopted our motivations and accepted our own necessities. In a word, that he has retained nothing African except the color. ${ }^{31}$

British experts were making the same point: "We cannot hope to produce an effective African labour force until we have first removed the African from the enervating and retarding influence of his economic and cultural background" (Kenya 1954:11).

Such thinking became widely accepted in French and British Africa by the mid-1950s. The French implemented their program of family allocations throughout their African domain in 1956: workers with several months of employment who registered marriages and births and whose wives and children submitted themselves to periodic medical examinations received a series of modest payments from before birth to completion of a child's schooling. ${ }^{32}$ British wage policy remained inconsistent, but the "bachelor wage" was complemented in Kenya and other colonies by a second minimum wage intended-however unrealistically-to cover the needs of a family, applied to workers with a record of stability in urban employment. In actuality 
urban wages ceased to cluster at the minimum as they had before the mid-1940s, while settler influence kept rural wages miserable (Cooper 1987:131, 158-162).

The powerful vision of a stable labor force developed in the decade after the war referred very little to research on African cities and workers; it had much more to do with the industrial sociology of advanced capitalist economies. ${ }^{33}$ Urban anthropology developed after the shift in official thinking. Although founded in 1937 in the heart of the Copperbelt, the Rhodes-Livingstone Institute and its innovative researchers were kept off the copper mines for a decade, and the pioneering urban research of J. C. Mitchell and A. L. Epstein began at the end of the 1940s. Around the same time, the founder of francophone urban anthropology, Georges Balandier, discovered "an Africa different from that which had been taught to me by the maitres des societés primitives," first among the intellectuals of Dakar and later among the poor of Brazzaville. ${ }^{34}$ Africanist urban research received an international intellectual imprimatur with the publication by UNESCO (1956) of the collective volume Social Implications of Industrialization and Urbanization in Africa South of the Sahara, some eight years after officials had begun their own international meeting to share their wisdom on the labor question. As urban anthropologists carved out a distinct domain for careful investigation, they were exploring what labor officials already claimed to know: that the African worker was a worker. French and British labor officials had reached by their own route the position staked out by Gluckman (1961:69), "An African townsman is a townsman, an African miner is a miner." 35

But for officials in the late 1940s and early 1950s, the idea that European knowledge was the key to understanding the African worker was something they desperately wanted to be true. The vision of African industrial man was a fantasy, an inversion of what officials feared was actually happening around them, of urban masses, of rootless workers, of migrants unable to cope with modern life. And as officials came to believe that an African worker could be modern, they developed an increasingly negative view of the African who was not. Indirect rule had implied a condescending vision of African life, but it conceded some complexity and integrity to African culture. Left in his own cultural milieu, the postwar African was, as in Conrad's Congo, the inversion of modern man.

In the last decade of colonial rule, the imagery of savagery and countersavagery, of terror and counterterror, reappeared in Africa, chillingly set against the bland universalism of industrial sociology. The Mau Mau revolt became a symbol to many Europeans of the atavism that still lurked within African culture. Trying to promote a more "stable" African working class, to improve agricultural techniques and to foster a class of progressive African farmers with solid titles to land and solid commitment to market production, and to use settler farms as an example of modern techniques and a source of export income, Kenya officials became captives of their own developmental ideology. They had no clear way of analyzing the grievances of people burdened by their soil conservation programs or of the squatters who were expelled from settler farms that were rationalizing production, only to find in their home districts a class of accumulating Africans eager to shed their social obligations. The ensuing revolt, in official accounts, became a rebellion against progress (Kanogo 1987; Throup 1987; Cooper 1988).

It was a self-serving, but not altogether false, charge: the squatters' had encountered not only white and black accumulators, but a universalistic ideology that defended accumulation in the name of free market justice, the legitimacy of private property, and economic progress, as well as Christianity and Western civilization. Against this powerful edifice, the forest fighters developed their own radical particularism, invoking a romanticized Kikuyu past. Guerrilla attacks were directed against those Kenyans most caught up in cultural as well as material terms in the modernism of postwar colonialism. The colonial state used the alleged savagery of the forest fighters to inflict its countersavagery: roundups, collective punishments of villages, concentration camps, and the forcing of prisoners through psychological rituals of admitting and repudiating their savagery (Cooper 1988). 
Mau Mau, which settlers and die-hard colonialists first saw as proof that firm European rule was necessary for the indefinite future, instead came to demonstrate that the costs of maintaining settler regimes amidst the contradictory imperatives of rationalizing production and stabilizing society were too high. The Gold Coast riots of 1948 had earlier signaled to British officials their incapacity to maintain order in cities burdened by officials' modernizing fantasies. The people whom they saw at the time as the demagogues likely to lead the mob into politicized violence would shortly emerge (sometimes from prison) to become the respectable African political class on which Britain could pin its hopes for avoiding mass unrest. Mau Mau revealed the worst fears and a possible solution, the dangers within African culture and the hope for molding a respectable political class, a respectable working class, and a respectable landowning class, sharing certain universal values. The fantasy of the modern and the fantasy of the savage shaped each other, and the frightening qualities of the latter led officials to want to believe ever more fervently that the former could be found.

\section{decolonization and the return of the purism of the market}

The debates over family allocations and family wages marked the apogee of colonial thinking about labor. They were part of a reassertion of control in a period of direct challenge from urban masses and organized workers and of growing anticolonial movements in many parts of the world. The reassertion of power within the workplace entailed playing down the "otherness" of the colonized and the "colonialness" of the state. Although the fear of African atavism betrayed a lack of confidence in the modern African, the search for a self-reproducing working class still put more faith in slow but ineluctable social processes than in the continual exercise of wise authority by European officials.

None of this explains decolonization, but the thinking about an important social problembeginning at a time when political independence was far from an acquired proposition- - hints at an intellectual process that made it possible to imagine an Africa that Europeans could understand, with which they could interact, but which they did not rule. ${ }^{36} \mathrm{~A}$ colonial problem did not have a colonial solution; the most immediate and plausible solution required thinking of African workers as workers more than as Africans. Nor was it clear that centrally managed development programs were going to be the new face of imperial authority that they had appeared to be for a brief moment after the war. By the mid-1950s, the aggressive hopefulness of the early planners was spent, sapped by grandiose plans that had gone wrong, costs that had escalated, commercial progress that could be wiped out by the smallest wobble in world markets, and social conflict that seemed to be exacerbated as often as eased by development efforts. The fervid hope for economic development had to be separated from problems of implementation and its consequences.

The new discourse on social questions was part of the means by which Western leaders and social scientists in the 1950 s convinced themselves that development and modernization were self-propelling processes. But when Europeans still governed, such a discourse was unstable and dangerous: colonial governments were confronted with all the difficult and unpredictable consequences of economic and social change as well as with the logical consequences of the new forms of imperial self-justification. The focus on social and economic development legitimized the European standard of living as a reference point for the aspirations of Africans. The argument could not be contained: the language in which officials discussed labor-and their yearnings for a stable and predictable African working class-implied that there was no logical stopping point short of providing wages and family allocations equal to those of European workers. It was extremely difficult for a colonial power to insist that it was right for a worker in Marseille to live in comparative security and for a worker in Dakar to live a life of misery even if the determinants of a market wage-the comparative affluence of French agriculture and the poverty of Senegalese-meant that each received a "just" wage. ${ }^{37}$ 
By the mid-1950s, one can begin to read signs of relief that African politicians were beginning to be confronted with the concrete problems of managing social change. In 1957, a number of politically active trade unionists in French West Africa prepared to contest elections. As responsible, if junior, ministers of a government, these officials would now be on the receiving end of labor demands, and French analysts expected that such African officials would respond as the French wished they could, giving "meager satisfaction." They hoped that dissatisfied workers would be held in check by "their respectful fear of local African authorities, who will not lack the means to make their point of view prevail." The British government, too, began to hope African politicians could resolve conflicts they themselves could not. ${ }^{38}$

Such thoughts were part of the crisis of self-confidence of late colonialism, and a step away from the intimate involvement with African society into which colonial governments had been thrust. The fantasizing of the African as industrial man could sometimes-as in modernization theory-reach as far as a totalizing vision of African society becoming modern. Eventually, decolonization removed the colonial powers from the social consequences of economic processes, from precisely what they had found impossible to avoid in the late 1940s and early 1950 s, both in international fora and in the streets of African cities.

Decolonization redefined the format and soon the contents of international discussion of living standards. Bodies like the United Nations and the World Bank made themselves the custodians of moral responsibility as well as of a large proportion of development finance. True to the kind of standards that it had been advocating since 1944, the ILO promoted in the 1970s a "basic needs approach" to development, arguing for the universality of certain human wants and the importance of a worldwide effort to meet them.

South Africa, meanwhile, has come to occupy in international moral discussions the place once taken by African slavery and King Leopold's Congo. Labor reforms analogous to those implemented in French and British colonies were discussed in the 1940s and rejected in favor of continued controlled migration and a denial that universal social norms applied to whites and blacks. But where decolonization has taken place, European wages and standards for labor conditions have gradually ceased to be the powerful reference point for Africa that they became in the 1940 s and 1950 s.

By the 1980 s, powerful voices were insisting that the free labor market was the only true guide to determining wages within each country, just as the world market was the best means of allocating resources among nations. Such discussions are international and they are moralistic: poor countries are told that they have seriously erred in paying their urban workers higher wages (or consumption subsidies) than their national labor markets justify. The International Monetary Fund has used its moral force and financial power to persuade 30 of the 45 subSaharan African countries to cut government social services and food subsidies for urban workers (Washington Post, 16 October, 1987). Academics give powerful support to such arguments, and use populist language to do so: the "urban bias" of African governments has hurt the rural poor. The arbiter of justice- the just wage, the just price, the just national income that a country with given resources can attain-is the market (Bates 1981; Lipton 1977). Such arguments tend to leave the rural producer as an asocial, acultural responder to market incentives, and they do not help to visualize what urban life would be like: how will the ragtag army of the miserably employed produce on the job and behave in the city?

This is just the question which French and British officials faced in the 1940s. They found their answer in an ethnocentric sociological fantasy and they could not reconcile it with the complexities of exercising power over people with their own visions and plans. The bounded universalism of industrial sociology was then challenged, if not displaced, by the even more universal claims of international economics.

The irony of the return of free market morality is that it is also coming home. Severed from the standards of labor relations and welfare of advanced industrial countries, removed from the protected markets of colonial empires, some ex-colonial countries, in Asia above all, have be- 
come successful enough at low-wage production to compete with the exports of old industrial countries. And so the reverse of what happened in the 1940s and 1950s begins to happen now: the standards of wages and benefits of the ex-colonies become a reference against which the ex-metropolitan powers need to measure themselves.

\section{conclusion: Ideology, social policy, and the tensions of rule}

This article has followed the tensions of imperial ideologies and colonial practices through four cycles: First, the idea, articulated in England between the late 19th century and the 1830s, that free labor would bring economic progress and social justice to slave colonies broke down by the 1860 s in the face of the complexities of forging a post-emancipation society and the alternative social visions that ex-slaves developed. The peculiarities of the Negro race were increasingly invoked to explain why West Indian laborers deviated from the universal expectations of classical economics.

Second, the European critique of African slaving and tyranny from the 1860 s to the 1890 s, which justified an interventionist imperial policy in the name of economic progress and social justice, broke down by the 1910s and early 1920s in the face of the difficulties of remaking rural African society. The peculiarities of African culture became an explanation for lack of progress, and social conservatism was proclaimed to be a positive good.

Third, the conservative colonial social agenda of the 1920 s broke down in the late 1930 s and 1940s in the face of the inescapable and disturbing presence of wage laborers in cities and mines, of the escalating demands being placed on African colonies, and of the hope that Africans could be industrial men.

Finally, the attempt to apply European concepts of industrial relations to African workers proved to be an inherently unstable ideological construct, legitimizing new demands on the colonial state while delegitimizing the control mechanisms of the colonial state itself. Decolonization, however, permitted the distancing of former rulers from the tensions and contradictions of economic change and a return to the abstract principles of free market justice.

Over these long years, several themes stand out. Beginning with Britain's leadership of an international movement against the slave trade-imperial ideologies were explicitly international and explicitly moralistic. Free labor ideology provided a singular, acultural concept of a just organization of labor, transcending divisions of state and religion. The moralistic and international dimensions of imperial ideology were reaffirmed at international conclaves from the Brussels Conference to ILO meetings and by ritualized criticism of select violators, a pattern continued in the post-colonial age.

From the 1830 s to the 1960 s, colonial powers' pursuit of a universalistic justification for their intervention into the organization of labor ran up against the complexities of social reproduction. The critique of forced labor in the Congo, as of the slave trade, emphasized that obtaining labor in such ways depended on reproducing labor forces outside the workplace, on predation of distant societies. This made impossible the generalization of commerce and a market in labor power. Making Europe's relationship to Africa capable of continuity and expansion implied the imposition-by force- of a new kind of government and a new intervention into social life. In practice, this proved beyond the means of Africa's colonizers. The failure of colonial schemes to make landowners into agricultural capitalists and slaves into workers left in its wake a variety of forms of production in African agriculture, some more easily harnessed to imperial needs than others, and a series of arrangements for extracting labor power from African societies without controlling the reproduction of that labor power.

The critiques of migrant labor that emerged in the late 1930s and became dominant in colonial policy in the late 1940s paralleled earlier critiques of slave labor. The question was what kind of worker African societies reproduced, and answering it brought colonial states to try to 
extend their control from the abode of production to the abode of reproduction. Whereas the migrant labor system and indirect rule assumed that African society possessed a unified traditionalism, while the African worker lived a dual existence between the workplace and the village, the postwar vision implied that African society was dualistic but the worker lived a unified existence. An African working class had to reproduce itself even if the costs of its reproduction exceeded the market wage.

The postwar view of African labor and the reproduction of an African working class rejected, on the face of it, racist notions of African difference, but embraced, in universalistic language, an ethnocentric vision of what society should be. That reveals a great deal about the assumptions that became deeply embedded in the postwar discourse of international agencies and academics, about the ways of thinking woven into conceptions of modernization and development that are still relevant today.

\section{notes}

'Under British pressure, the Congress of Vienna affirmed in 1815 that the slave trade violated the standards of civilized nations, thereby setting a precedent for delineating international moral principles (Miers, 1975).

${ }^{2}$ These phrases are from leading Colonial Office officials, Henry Taylor (1833), James Stephen (1832), and Lord Clenelg (1836) quoted in Holt (forthcoming) and Davis (1984:218).

${ }^{3}$ Livingstone (1865:595). See also Davis (1984), Miers (1975), Cooper (1980).

${ }^{4}$ This critique was similar to that which missionaries in 19th-century South Africa were making of white settlers (Comaroff, this volume).

${ }^{5}$ Some West African merchants espoused a kind of cultural relativism in the 1890 s that only becamein a quite different form-British imperial dogma in the 1920s. See Rich (1986).

${ }^{6} \mathrm{H}$. H. Johnston, British Commissioner to Central Africa, initially denied in 1892 that he was on "any Quixotic or expensive crusade against slavery," but soon was boasting of his attacks on slavetraders and for bringing "peace and security" to the population. Dispatches and reports reprinted in Parliamentary Papers, 1892, LXXIV, 511, p. 34; 1896, LVIII, 375; ibid., 423, pp. 12, 14.

${ }^{7}$ W. E. Taylor to Henry Binns, 26 July 1895, Parliamentary Papers, 1896, LIX, p. 18. For the argument as a whole, see Cooper (1980).

${ }^{8}$ Assistant District Commissioner, Kilifi, to Provincial Commissioner, 18 October 1918, Kenya Archives, CP 38/582; Report of Inspector Maret, Ivory Coast, No. 125, 25 May 1931, AP 3066, France, Archives Nationales, Section Outre Mer (hereafter ANSOM). When the Kenya Government in 1919 injudiciously said it would "encourage" African labor to work for settlers, it unleashed a storm and had to withdraw the word-although not necessarily the policy.

${ }^{9}$ See the correspondence of the French Minister, Marius Moutet, 1937-39, in AP 2807/3, and PA 28/5/ 143, ANSOM, and the cautious missionary critique of Kenyan Government labor policy in Parliamentary Papers, 1920, XXXIII, 81, pp. 8-10.

${ }^{10}$ Major G. St. J. Orde Browne. "Labour Conditions in East Africa," Colonial No. 193, 1946, pp. 5-6; Ivory Coast, Inspection du Travail, Annual Report, 1936; notes on European and indigenous colonization in French West Africa, for the Commission of Enquiry, 1935, PA 28/5/152, ANSOM.

"The pastoral vision of the Popular Front is documented in Moutet's papers, PA 28, ANSOM. Pathological imagery is found in Northern Rhodesia (1935) and Eboue (1945), and the issue is analyzed in Cooper (1987).

${ }^{12}$ Governor General de Coppet to Minister, 25 January 1937, K 8 (1), Archives du Sénégal (hereafter AS).

${ }^{13}$ Occasionally, British and French officials wondered if the once-condemned Belgians might have found a more advanced approach, but they were not yet ready to imitate it. In the mining regions of the Congo, labor turnover was kept low, and government policy enforced both minimal standards of welfare and strong discipline on a workforce that was more sharply separated from the rest of the African population than was the norm elsewhere. But the Depression led even the Belgians to reverse direction, letting African society take up the burden of social security (Vellut 1981).

${ }^{14}$ In the 1930s, the first extended critiques of migrant labor appeared, as did the first official studies of the standard of living of colonial people. See First Report of the Committee on Nutrition in the Colonial Empire. Parliamentary Papers, 1938-39, X, 55; Davis (1933); and Wilson (1941).

${ }^{15}$ Arthur Creech Jones, Parliamentary Debates 348:(7 June 1939):487.

${ }^{16}$ Earlier, the Popular Front government (1936-38) had a brief foray into the world of work. Despite its bucolic rhetoric and pro-peasant policies, it wanted modified metropolitan legislation applied to wage 
laborers whose presence was necessary. In practice, this approach applied only where workers engaged in strikes or union organizing, notably in Senegal. See Bernard-Duquenet (1986).

${ }^{17}$ La Conférence Africaine Française (Brazzaville: Editions du Baobab, 1944), p. 55; "Role et place des européens dans la colonisation," and "Programme général de la Conférence de Brazzaville," papers prepared for the conference, 1944, Affaires Politiques 2201/4 and 2201/7, ANSOM.

${ }^{18}$ Annales de l'Assemblée Nationale Constituante 2 (1 March 1946):548, 4(5 April 1946):1514.

${ }^{19}$ Ivory Coast, Inspection du Travail, Annual Reports, 1944-47. Similarly, the annual migration of people, known as navétanes, from the Western Sudan onto the peanut farms of Senegal, came under the rubric of customary labor.

${ }^{20}$ Governor General to Minister, 10 January 1946 (telegram), Inspection Général du Travail (hereafter IGT) 12/3, ANSOM; Inspecteur du Travail Masselot to Minister of Colonies, 23 February 1946, Affaires Politiques 960, ANSOM. These pages draw on my ongoing comparative study of British and French thinking about labor and African society in the period 1935-60.

${ }^{21}$ Inspecteur du Travail, Senegal, to Secretaire Général, 13 May 1947, and "notes d'études sur I'appel de la sentence surarbitrale du 24 avril 1947, 29 April 1947, IGT 12/3, ANSOM; Inspecteur due Travail, A.O.F., Circulaire aux Inspecteurs du Travail, 4 March 1949, K 414 (144), AS; A.O.F., Inspection du Travail, Annual Report, 1948.

${ }^{22}$ Transcript of meeting between union officials and government representatives, 15 January 1946, K 405 (132), and Governor General to Minister, 30 March 1946, K 327 (26), AS.

${ }^{23}$ Inter-African Labour Conference, First Meeting, Jos, 1948, and Second Meeting, Elizabethville, 1950 , both reprinted in Commission for Technical Co-operation in Africa South of the Sahara, Labour. Inter-African Conference. IVth meeting, Beira, Mozambique, 1955, pp. 51-55, 59-65.

${ }^{24}$ Third meeting, Bamako, 1953, pp. 75-76.

${ }^{25}$ Governor General to Minister, 12 January 1950, K 424 (165), AS.

${ }^{26}$ Governor General to Minister, telegram 22 November 1955, K 418 (144), AS.

${ }^{27}$ A.O.F., Rapport biannuel sur la protection de la collectivité, de la famille et de l'enfance, 1951-52, 2 G 52-3, AS; Note for the Minister on "les prestations familiales dans les territories d'outre mer," n.d. [1953-54], IGT 15/1, ANSOM; Minister's Circular to Governors-General, 3 September 1953, IGT 15/3, ANSOM; Pierre Pélisson, "Etude préliminaire de l'institution des prestations familiales," 28 September 1958, IGT 16/1, ANSOM; Conseil Supérieur du Travail, transcript of session of 13 November 1954, IGT, $2 / 2$, ANSOM.

${ }^{28}$ See the files in IGT, cartons 15 and 16, ANSOM. On Belgian approaches to the surveillance of workers' wives, see Hunt (1988).

${ }^{29}$ Governor-General, French West Africa, to Minister, 14 October 1955, and Inspecteur Général du Travail, "Prestations familiales: état au 10 mars 1956," IGT, 15/1, AS; note from the Inspecteur Général du Travail to Minister, 26 July 1954, IGT 2/1, ANSOM.

${ }^{30}$ Subcommittee on Wage-Fixing and Family Responsibilities of the Colonial Labour Advisory Committee, meeting of 28 July 1953; draft paper for Colonial Labour Advisory Cornmittee, 9 May 1953, CO 859/ 257, PRO; Oliver Lyttleton, Circular Letter, 2 June 1954, copy in Railway Archives, Nairobi, EST 26/26/1. Lyttleton's Labour predecessor as Colonial Secretary said about trade unions what the Tory said about the market: "reasonable wages" must be paid workers even if the bargaining skills of their unions were not good enough to win them. James Griffiths, Circular Despatch, 26 July 1951, CO 859/183/12254, PRO.

${ }^{31}$ A.O.F., Inspection du Travail, Office d'Etudes Psychotechniques, "Quelques Aspects de la psychologie africaine," July 1953, pp. 48-49.

${ }^{32} \mathrm{~A}$ worker in the Ivory Coast would receive 13,200 francs (twice the monthly wage of a semi-skilled worker) during the pregnancy and first year of a child's life, plus 400 francs per month until the child left school. Ivory Coast, Inspection du Travail, Annual Report, 1957.

${ }^{33}$ For a review of studies of industrial work, see Burawoy (1979). Thinking about the universality of modern work culture reached its peak in the concept of "industrial man" defended most vigorously in the 1950s by Clark Kerr.

${ }^{34}$ See Balandier's memoirs (1977) and the fine history of the Rhodes-Livingstone Institute by Brown $(1973,1979)$. Earlier, scholars contributed to the humanitarian discourse on labor within the free labor traditions of Casement and others. See for example the contributions to Davis (1933) and the indictment of forced labor in French Africa written in 1945 by the anthropologist Michel Leiris and the geographer Jean Dresch (reprinted in Dresch, 1979). Wilson (1941) can be read as a combination of the humanitarian critique-extended from forced to migrant labor-and a sociological approach to the urban situation.

${ }^{35}$ The exact relationship between official and scholarly discourses on these subjects remains to be elucidated. Brown notes (1979:535) that Gluckman was already arguing in 1943 that African life in city and country belonged to two structurally distinct domains that could be studied separately. He speculates that this was in part a "defensive reaction" to the fact that he was not then allowed to do research in both but also notes that it was part of anthropology's contemporary conception that the social units one studies should be conceived of as functioning wholes.

${ }^{36}$ This imagining of new social structures throughout the world is the flip side of the imagining of the nation in Anderson's (1983) interpretation of nationalism. 
${ }^{37}$ Such a comparison was made explicitly in a French study, "Comment vit un travailleur africain au Sénégal?"' K 455 (179). AS.

38" Note sur l'évolution du syndicalisme en A.O.F.," 19 April 1957, IGT 11/2, ANSOM: Cooper (1987).

\section{references}

Anderson, Benedict

1983 Imagined Communities: Reflections on the Origin and Spread of Nationalism. London: Verso.

Balandier, Georges

1977 Histoire des autres. Paris: Stock.

Bates, Robert

1981 Markets and States in Tropical Africa. Berkeley: University of California Press.

Beidelman, T. $O$.

1982 Colonial Evangelism. Bloomington: University of Indiana Press.

Berman, Bruce, and Lonsdale, John

1980 Crises of Accumulation, Coercion and the Colonial State: The Development of the Labour Control System in Kenya, 1919-1929. Canadian Journal of African Studies 14:37-54.

Bernard-Duquenet, Nicole

1986 Le Sénégal et le Front Populaire. Paris: Harmattan.

Brown, Richard

1973 Anthropology and Colonial Rule: Godfrey Wilson and the Rhodes-Livingtone Institute. pp. 173197 in Talal Asad (ed.), Anthropology and the Colonial Encounter. London: Ithaca Press.

1979 Passages in the Life of a White Anthropologist: Max Gluckman in Northern Rhodesia. Journal of African History 20:525-541.

Burawoy, Michael

1979 The Anthropology of Work. Annual Review of Anthropology 8:131-166.

Cairns, H. Alan C.

1965 Prelude to Imperialism: British Reactions to Central African Society 1840-1890. London: Routledge \& Kegan Paul

Constantine, Stephen

1984 The Making of British Colonial Development Policy 1914-1940. London: Cass.

Cooper, Frederick

1980 From Slaves to Squatters: Plantation Labor and Agriculture in Zanzibar and Coastal Kenya, 18901925. New Haven: Yale University Press.

1981 Africa and the World Economy. African Studies Review 24:1-86.

1987 On the African Waterfront: Urban Disorder and the Transformation of Work in Colonial Mombasa. New Haven: Yale University Press.

1988 Review Article: Mau Mau and the Discourses of Decolonization. Journal of African History 29:313-320.

Davis, David Brion

1974 The Problem of Slavery in the Age of Revolution, 1770-1823. Ithaca: Cornell University Press.

1984 Slavery and Human Progress. New York: Oxford University Press.

Davis, J. Merle

1933 Modern Industry and the African. London: Macmillan.

Dresch, Jean

1979 Un géographe au déclin des empires. Paris: Maspero.

Duffy, James

1967 A Question of Slavery. Oxford: Oxford University Press.

Eboué, Félix

1945 La Nouvelle politique indigène pour l'Afrique Equatoriale Française. Paris: Office Française d'Edition.

Echenberg, Myron, and Jean Filipovich

1986 African Military Labour and the Building of the Office du Niger Installations, 1925-1950. Journal of African History 27:533-551.

Fall, Babacar

1984 Le Travail forcé en A.O.F. 1900-1946; cas du Sénégal, de la Guinée et du Soudan. Doctorat du troisième cycle, Université de Dakar.

Gluckman, Max

1961 Anthropological Problems arising from the African Industrial Revolution. pp. 67-82 in Aidan Southall (ed.) Social Change in Modern Africa. London: Oxford University Press.

Harris, J. $\mathrm{H}$.

1919 Africa: Slave or Free? London: Student Christian Movement.

Holt, Thomas $M$.

Forthcoming The Problem of Freedom: Labor, Race, and Politics in Jamaica and Britain, 1830-1930.

Hunt, Nancy

1988 'Le Bébé en Brousse': European Women, African Birth Spacing and Colonial Intervention in Breast Feeding in the Belgian Congo. International Journal of African Historical Studies 21:401-432. 
International Labour Organization

1929 Forced Labour, Report and Questionnaire. Geneva.

1939 Conventions and Recommendations, 1919-1937. Geneva.

1944 Recommendation [No. 70] concerning minimum standards of social policy in dependent territories. 26th International Labour Conference, Philadelphia.

1947 The 30th Session of the Conference. International Labour Review 56:264-269.

Kanogo, Tabitha

1987 Squatters and the Roots of Mau Mau. London: James Currey.

Kenya

1945 Report of the Committee of Inquiry into Labour Unrest at Mombasa. Nairobi.

1954 Report of the Committee on African Wages. Nairobi.

Killingray, David

1986 Labour Mobilisation in British Colonial Africa for the War Effort, 1939-46. pp. 68-96 In Killingray and Richard Rathbone, eds. Africa and the Second World War. New York: St. Martin's Press.

Klein, Martin

1986 "Slavery and Emancipation in French West Africa. Paper for a colloquium at the Woodrow Wilson Center. June 1986.

Lennihan, Louise D.

1982 Rights in Men and Rights in Land: Slavery, Labor and Smallholder Agriculture in Northern Nigeria. Slavery and Abolition 3:111-139.

Lewis, W. Arthur

1954 Economic Development with Unlimited Supplies of Labour. The Manchester School 22:139191.

Lipton, Michael

1977 Why Poor People Stay Poor: Urban Bias in World Development. Cambridge, MA: Harvard University Press.

Livingstone, David

1865 Narrative of an Expedition to the Zambesi and Its Tributaries. London: Murray.

Louis, Wm. Roger

1978 Imperialism at Bay: The United States and the Decolonization of the British Empire, 1941-1945. New York: Oxford University Press.

Lovejoy, Paul E.

1983 Transformations in Slavery: A History of Slavery in Africa. Cambridge: Cambridge University Press.

Lugard, Frederick

1906 Instructions to Political and Other Officers. London: Waterlow.

1922 The Dual Mandate in British Tropical Africa. London: Blackwood.

Marseille, Jacques

1984 Empire colonial et capitalisme français: Histoire d'un divorce. Paris: Albin Michel.

Michel, Marc

1983 La coopération intercoloniale en Afrique noire, 1942-1950: un néocolonialisme éclairé? Relations Internationales 34:155-171.

Miers, Suzanne

1975 Britain and the Ending of the Slave Trade. New York: Africana.

Miers, Suzanne, and Richard Roberts, eds.

1988 The End of Slavery in Africa. Madison: University of Wisconsin Press.

Moreux, René

1953 Les textes d'application du Code du travail dans les Territoires d'Outre Mer doivent être à la fois loyaux et prudents. Marchés Coloniaux 9, 381 (28 February 1953):610.

Northcott, C. H.

1949 African Labour Efficiency Survey, Colonial Research Publications No. 3. London.

Northern Rhodesia

1935 Report of the Commission Appointed to Enquire into the Disturbances in the Copperbelt, Northern Rhodesia. Lusaka.

Parpart, Jane

1983 Labor and Capital on the African Copperbelt. Philadelphia: Temple University Press.

Ranger, Terence

1983 The Invention of Tradition in Colonial Africa. pp. 211-262 in Eric Hobsbawm and Terence Ranger, eds. The Invention of Tradition. Cambridge: Cambridge University Press.

Rich, Paul B.

1986 Race and Empire in British Politics. Cambridge: Cambridge University Press.

Sundiata, Ibrahim

1980 Black Scandal: America and the Liberian Labor Crisis, 1929-1936. Philadelphia: Institute for the Study of Human Issues.

Taussig, Michael

1987 Shamanism, Colonialism, and the Wild Man: A Study in Terror and Healing. Chicago: University of Chicago Press. 
Throup, David W.

1987 Economic and Social Origins of Mau Mau. London: James Currey.

UNESCO

1956 Social Implications of Industrialization and Urbanization in Africa South of the Sahara. Paris: UNESCO.

van Onselen, Charles

1976 Chibaro: African Mine Labour in Southern Rhodesia 1900-1933. London: Pluto.

Vellut, Jean-Luc

1981 Les Bassins miniers de l'ancien Congo Belge: Essai d'histoire économique et sociale (19001960). Cahiers Du CEDAF 7.

Wilson, Godfrey

1941 An Essay on the Economics of Detribalisation in Northern Rhodesia. Livingstone: Rhodes-Livingstone Institute.

submitted 8 March 1989

accepted 6 July 1989

final version received 10 July 1989 